\title{
Evaluating Site Selection Criteria for Marine Cultivation in North Lombok Regency of Indonesia through GADA model
}

\author{
Ellen Thio ${ }^{1, *}$ \\ ${ }^{1}$ School of Business, Nanjing University of Information Science and Technology, Nanjing, China \\ *Corresponding author: thio_ellen@yahoo.com
}

Received 22 May 2021; Revised 7 June 2021; Accepted 10 June 2021

\begin{abstract}
Identifying the requirements for selecting water locations for marine cultivation requires identifying and objectively selecting cultivation locations. The study aims to identify site selection criteria to develop marine cultivation in Indonesia's North Lombok Regency, followed by their prioritization based on perceived significance. The selection criteria are through extensive review of literature, and are evaluated based on primary data. Grey Absolute Decision Analysis (GADA) model was used to evaluate the criteria. Comparative analysis with the Simple Additive Weighting (SAW) and TOPSIS methods confirmed the soundness of the results obtained through GADA. It was found that oceanographic conditions are most essential criterion for site selection for marine cultivation development. The results are important for marine cultivation businesses looking for suitable site in North Lombok Regency.
\end{abstract}

Keywords: Water location; marine cultivation; development; grey system theory; multiple criteria decision making

\section{Introduction}

Indonesia is located between the Australia-Asia continents, the Indian-Pacific Ocean, and is one of the world's emerging economies. Among its essential exports includes textile, rubber, and palm oil, among others. Indonesia is the world's second largest producer of fisheries after China (FAO, 2020). In 2018, the contribution of fisheries and fish industry to the Indonesian GDP was 2.7\% (Statista, 2020). Therefore, the government's effort in implementing the Fishery Product Export Improvement Program is to develop marine cultivation. High productivity from aquaculture expects to take over capture fisheries production (Widodo, 2001) through resource optimization and the application of science (Meske \& Vogt, 1985). The importance of aquaculture activities in increasing fishery products, such as restocking, stock enhancement, and farming biota is known through literature (Gimin, 2001). Cultivation is an activity that is most likely to be applied considering the high level of productivity, both the unity of organisms, land, and time.

North Lombok Regency (NLR) is one of Indonesia's coastal districts, with a coastline of about 125 $\mathrm{km}$. The coastal and marine area has many caves, potential areas for aquatic cultivation (mariculture) development. According to Utojo and Mansyur (2007), the location can carry out the development of mariculture businesses such as coastal areas (bays) because they can protect from the influence of strong currents, large waves, strong winds, and free of pollution. Mariculture has a lively and bright prospect to be developed to increase coastal communities' income, raise local revenue, increase country foreign 
exchange, and avoid environmental damage (Junaidi et al., 2018). Pearl shells, seaweed, lobster, and grouper are marine fishery commodities that are frequently exported, and these four commodities are primarily developed in North Lombok Regency (see Table 1). However, they are still on a small and simple scale. The demand and price of these commodities in the domestic and international markets continue to increase every year. It shows that marine cultivation is the right solution to reduce coral reef ecosystems' damage due to irresponsible fishing that recently often occurs in Northern Lombok.

The interaction between the culture biota and the outside environment is robust and almost no barrier. Based on the history of cultivation in various parts of the world, selecting the right location is essential in determining the feasibility of cultivation (Milne, 1979). Some non-conforming units can become profitable or even forces to abandon them after spending a fortune, even with technology ventures. Therefore, location selection is crucial for the success of cultivation (Sukandi, 2002; Muir \& Kapetsky, 1998). Therefore, choosing the right and good criteria of the location is one of the determining factors for marine cultivation and the availability of seeds, feed, and guaranteed markets and prices (Affan, 2011). Species usually determine the determination of cultivation. However, the review of the availability of these factors is incomplete. Water quality, as one of them, will affect the determination of other supporting elements. Another essential consideration factor is the location's biographical parameters to be reviewed (physical, chemical, and biological, non-technical parameters, namely market, security, and human resources (Pillay, 1990; Milne, 1979). In cultivation development, a problem that often arises is improper environmental selection. Therefore, proper and detailed data are needed. However, the problem occurs is the placement of mariculture locations is predictive, so needs an accurate description criterion and avoiding non-supportive environmental influences (Radiarta et al., 2005). Therefore, by extending the work by Junaidi et al. (2018) and Szuster and Albasri (2010), the current study identifies the site selection criteria for marine cultivation development in North Lombok Regency followed by its evaluation.

In the current study through exnsive review of literature some criteria will be identified for proper site for marine cultivation, and later using an emerging multi-criteria decision-making approach (MCDM), called Grey Absolute Decision Analysis (GADA) model, the criteria will be evaluted. The study will also use two other MCDM models for comparative analysis purpose. The study is organizes as follows: after introduction, the literature review is presented, which expects to provide an overview and essential points about the basics that are in line with the learning theme, namely overview of marine cultivation in Indonesian and North Lombok Regency. The criteria identification is also performed. In the third part, the methodological approach and models are discussed. The next part is regarding results and discussion where relative weights and rankings are obtained. In the last part, the conclusions and recommendations are presented for the readers.

\section{Literature Review}

\subsection{Marine Cultivation Development in Indonesia}

Mariculture is the cultivation of marine organisms for food and other products such as medicines, food additives, jewelry (for example, cultured pearls), nutraceuticals, and cosmetics, either in a natural marine environment or in terrestrial or aquatic cages, such as cages, ponds, or raceways. Seaweed, mollusks, shrimp, sea fish, and various other small species such as sea cucumbers and seahorses are among the multiple organisms currently cultivated around the world's coastlines. The fact is that the cultivation development location's determination is more based on feeling or trial and error (Hartoko \& Helmi, 2004). Data or information about site suitability is essential to solving coastal use competition (Radiarta et al., 2005). Proper management of aquatic resources expects appropriate suitability for each intended use of these resources. Therefore, packaging and arrangement are necessary (Zonneveld $e t$ al., 1991). The development of mapping technology can determine the cultivation location (Budiyanto, 2005; Torres et al., 1988). The technology application used to describe the site for the development of marine culture combined with the aquatic ecosystem's parameters.

Indonesia is the largest archipelago country globally with a manageable sea area of 5.8 million $\mathrm{km} 2$, a vast diversity of marine and fishery resources. The Maximum Sustainable Yield (MSY) potential in Indonesia's marine territory is 6.5 million tons each year, with the permitting amount can be caught 5.2 million tons each year (Decree of the Minister of Marine Affairs and Fisheries of the Republic of 
Table 1. Marine Fisheries Production by kind of Fish, 2010-2016 in NLR (Source: TMAF, 2021)

\begin{tabular}{|c|c|c|c|c|c|c|c|}
\hline \multirow{2}{*}{ Type of Fish } & \multicolumn{7}{|c|}{ Production ( Ton ) } \\
\hline & 2010 & 2011 & 2012 & 2013 & 2014 & 2015 & 2016 \\
\hline Lizard Fish & 291.40 & - & 126.00 & 101.10 & 107.70 & 115.50 & 414.50 \\
\hline Groupers & 189.00 & 7.00 & - & - & 362.30 & 240.00 & 161.80 \\
\hline Emperarsd & - & - & 541.10 & - & - & - & - \\
\hline Threadfin & 189.00 & 313.20 & 2.60 & 430.30 & 408.80 & 400.00 & 298.90 \\
\hline Big Eyes & - & - & 4.10 & - & - & - & - \\
\hline Yellow Tail & - & - & 2.30 & - & - & - & 37.30 \\
\hline Sharde & 2.20 & 7.00 & - & - & - & - & - \\
\hline Rays & 2.20 & 457.81 & - & 4.30 & 4.30 & - & - \\
\hline Barracudas & - & - & - & - & - & - & 3.60 \\
\hline Scard & $1,457.60$ & 991.50 & - & $1,490.70$ & $1,419.30$ & $1,525.50$ & $1,140.90$ \\
\hline Trevallises & $1,165.40$ & 693.40 & 637.10 & 14.00 & 11.80 & 12.80 & 603.90 \\
\hline Jacks & 1.30 & - & 14.70 & - & - & - & 15.50 \\
\hline $\begin{array}{l}\text { Rainbow } \\
\text { Rumors }\end{array}$ & - & - & - & - & - & 75.5 & - \\
\hline Flying Fish & - & - & - & - & - & $1,175.00$ & - \\
\hline Gar Fish & 890.10 & 119.00 & 417.40 & 335.40 & 360.20 & 380.50 & 261.50 \\
\hline Anchivies & 187.00 & 211.00 & 94.50 & 149.90 & 157.10 & 160.20 & 0.80 \\
\hline Fringascale & 291.80 & 516.90 & 126.45 & 101.10 & 113.70 & 115.50 & $1,056.80$ \\
\hline $\begin{array}{l}\text { Indian Oil } \\
\text { Sardinella }\end{array}$ & 601.80 & 458.90 & 304.70 & 312.40 & 318.80 & 321.70 & 373.40 \\
\hline Indo Pacific & 582.70 & 147.50 & 285.70 & 98.30 & 344.30 & 370.50 & - \\
\hline Narrow Barred & 52.50 & 313.70 & 192.20 & 157.40 & 152.20 & 150.30 & 287.00 \\
\hline Hairtail & 191.80 & - & 538.80 & 425.30 & 419.40 & 420.40 & 74.80 \\
\hline Skip Jack Tuna & 659.70 & 756.70 & - & - & - & - & 9.20 \\
\hline Eastern Tuna & - & - & $1,261.30$ & $1,135.70$ & $1,215.80$ & $1,217.50$ & 644.50 \\
\hline Other Fish & 2.20 & 363.30 & - & - & 26.00 & - & 169.20 \\
\hline Other Shrimp & 16.70 & - & - & 27.10 & 19.00 & - & 0.30 \\
\hline Cammond & 189.00 & - & 21.20 & 19.20 & 19.00 & 19.75 & 168.90 \\
\hline Kuniran & - & - & - & 430.30 & 408.30 & 416.40 & 130.80 \\
\hline Gurita & - & - & - & 8.7 & 8.7 & 8.8 & 9.6 \\
\hline Kerapu Karang & - & - & - & 365.6 & 357.7 & - & - \\
\hline Kerapu Bebek & - & - & - & 5.1 & 4.6 & 0.24 & - \\
\hline Baronang & - & - & - & 304.5 & 317.7 & 315.7 & 326.1 \\
\hline Rejung & - & - & - & 4 & 3.9 & - & - \\
\hline Pari & - & - & - & 3.1 & 4.3 & 3.5 & - \\
\hline Udang digol & - & - & - & 8.2 & 8.7 & - & - \\
\hline Udang Krosok & - & - & - & 8.1 & 8.8 & - & - \\
\hline Udang Karang & - & - & - & 2.5 & 8.4 & 7.4 & - \\
\hline Total & $6,963.40$ & $5,386.91$ & $4,569.52$ & $5,942.30$ & $6,571.80$ & $7,452.69$ & $6,189.30$ \\
\hline
\end{tabular}

Indonesia Number KEP. 45 / MEN / 2011 regarding Potential Estimation of Fish Resources in the Indonesian Fisheries Management Area). For aquaculture, its potential is seawater cultivation of 8.3 million hectares (consisting of $20 \%$ for fish cultivation, $10 \%$ for shellfish cultivation, $60 \%$ for seaweed cultivation, and $10 \%$ for others). Indonesia is among top producers of fisheries and and aquaculture production in the world consistently from several years (FAO, 2020). It explains enormous opportunities for Indonesian fisheries. If cultivation manages carefully and responsibly, it will become a sustainable activity and boost Indonesia's development capital in the present and future.

\subsection{North Lombok Regency - Location and marine cultivation}

The North Lombok Regency is very strategically located in the golden triangle area of a tourism destination, as shown in Figure 1. The sea transportation route with the Lombok Strait is used as an increasingly busy sea transportation route, from the middle east for fuel oil traffic and from Australia in metal minerals to the Asia Pacific. There are three island clusters known as Gili Matra (Meno, 


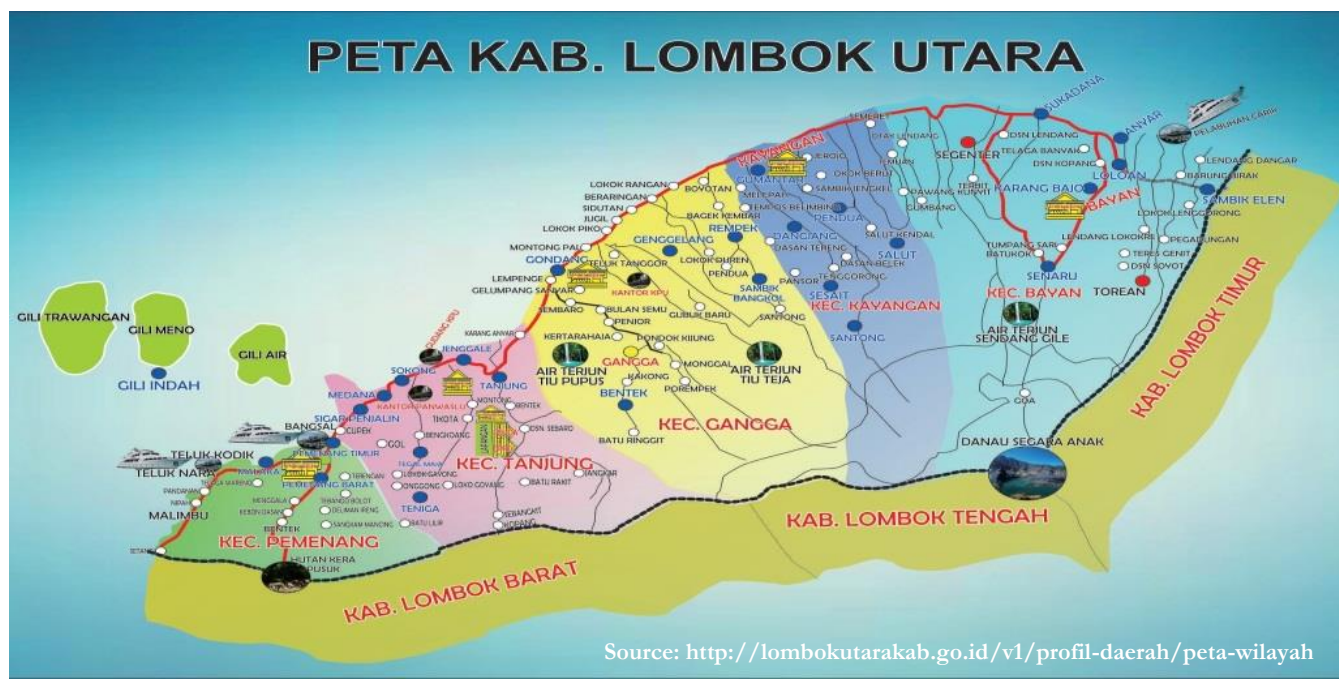

Figure 1. Map of the North Lombok Regency of Indonesia

Trawangan, and Air), marine tourism areas that are very well known to foreign nations as a beautiful and enchanting tourist destination. Besides being used as marine tourism, North Lombok coastal marine resources' potential is partly utilized as aquaculture and capture fisheries areas (Junaidi et al., 2018).

Based on data from the Meteorology and Geophysics Agency, North Lombok Regency is classified as a tropical area with temperatures ranging from $23.1^{\circ} \mathrm{C}$, with the highest temperature occurring in July-August $32.9^{\circ} \mathrm{C}$ and the lowest in April, namely $20.9^{\circ} \mathrm{C}$. Marine cultivation activities in North Lombok waters are already ongoing and are limited to several cultivation systems and commodities. The cultivation system used is floating nets and rafts, while the things cultivated include Tiger Grouper (Epinephelus Sp), Star Pomfret (Trachnotus Carolinus), Seaweed (Euchema Vottonii), and Pearl Shellfish (Pinctada Maxima).

North Lombok Regency (NLR) located in West Nusa Tenggara Province, with a position between $08^{\circ} 21$ '42 "South Latitude and 116 09' 54" East Longitude, with boundaries areas as follows:

- North: Java Sea

- Westside: Lombok Strait and West Lombok Regency

- Southside: West Lombok Regency and Central Lombok Regency

- Eastside: East Lombok Regency

Tanjung is the capital of North Lombok Regency, which is also the center of Government. North Lombok Regency has a land area of $809.53 \mathrm{~km}^{2}$ consisting of particular regions (protected forests, wildlife areas, etc.) covering an area of $361.86 \mathrm{~km}^{2}(44.30 \%)$ and the remaining flat land for agricultural land, etc. covering $447.67 \mathrm{~km}^{2}(55.30 \%)$. The size of North Lombok waters is $594.71 \mathrm{~km}^{2}$ with a beach length of $127 \mathrm{~km}$. Administratively, North Lombok Regency is divided into 5 Districts, 33 Villages and 371 Hamlets, of which Bayan District has the largest area with a land area of $329.10 \mathrm{~m}^{2}(40.66 \%)$ and the smallest is Pemenang District with a land area of $81.09 \mathrm{~km}^{2}(10.01 \%)$, as shown in Table 2 .

North Lombok Regency (NLR) is an important area for marine curltivation in Indonesia. The fishery in several areas along the coast of North Lombok Regency (NLR) has become the sub-sector of residents' choice to depend on their livelihoods. Most of the fishermen in North Lombok Regency are fishermen who catch fish in the sea, and only a small portion cultivate freshwater fish (flying fish and

Table 2. The Area of North Lombok Regency (Detailed by District)

\begin{tabular}{|c|c|c|c|c|c|c|c|}
\hline \multirow{2}{*}{ No. Sub-District } & \multicolumn{3}{|c|}{ Total Area } \\
\cline { 3 - 7 } & & \multicolumn{2}{|c|}{ Mainland } & \multicolumn{2}{c|}{ Sea } & \multicolumn{2}{c|}{ Total } \\
\cline { 3 - 7 } & & $\mathbf{k m}^{2}$ & Percentage & $\mathbf{k m}^{\mathbf{2}}$ & Percentage & $\mathbf{k m}^{2}$ & Percentage \\
\hline 1 & Pemenang & 81.09 & $10.01 \%$ & $*$ & $*$ & 81.09 & $5.77 \%$ \\
\hline 2 & Tanjung & 115.64 & $14.28 \%$ & 302.26 & $50.82 \%$ & 417.90 & $29.76 \%$ \\
\hline 3 & Gangga & 157.35 & $19.44 \%$ & 100.33 & $16.87 \%$ & 257.68 & $18.35 \%$ \\
\hline 4 & Kayangan & 126.35 & $15.61 \%$ & $*$ & $*$ & 126.35 & $9.00 \%$ \\
\hline 5 & Bayan & 329.10 & $40.66 \%$ & 192.12 & $32.30 \%$ & 521.22 & $37.12 \%$ \\
\hline & Total & 809.53 & $100.00 \%$ & 594.71 & $100.00 \%$ & $1,404.24$ & $100 \%$ \\
\hline
\end{tabular}


selar fish commonly caught). Production of tembang and selar fish in 2014 was 1,490.7 tons and 903.9 tons, respectively. Meanwhile, the most popular type of freshwater fish is tilapia. Tilapia production in 2014 reached 14.5 tons. In Table 1, the marine fisheries production is summarized for the region.

\subsection{Identification of Criteria for Marine Cultivation}

In this section, based on the literature, site selection criteria are identified. The result of this effort is shown in Table 3. In the table, $\mathrm{C}$ represents manin criteria and SC represent sub-criteria. The first criterion is the biophysical parameters. It is the first point and the most critical factor in determining the cultivation location because development for mariculture efforts does not escape the supporting elements of nature, the situation, and natural conditions. Environmental factors also one of the support that can't be left, namely humans who work in cultivation, facilities, and the help from the surrounding environment in the cultivation process. Ecological factors also support marine cultivation, which promotes the preservation of the local marine ecosystem.

Table 3. The Criteria and Sub-Criteria for Marine Cultivation

\begin{tabular}{|c|c|c|c|}
\hline & Criteria (and Sub-Criteria) & Description & Literature \\
\hline C1 & BIOPHYSICAL PARAMETERS & & FAO (2000; 1989) \\
\hline MC1 & Oceanographic conditions & $\begin{array}{l}\text {-Tidal: feasibility testing in cultivation } \\
\text { development. } \\
\text { - Seabed conditions: plays an essential } \\
\text { role in the ecosystem biota. }\end{array}$ & Szuster and Albasri (2010) \\
\hline MC2 & Water quality & $\begin{array}{l}\text { - Water PH: an overview of the } \\
\text { appropriate marine commodities. } \\
\text { - Salinity: ability to penetrate light into } \\
\text { the waters/photosynthesis process. } \\
\text { - Dissolved oxygen conditions } \\
\text { - Water temperature conditions } \\
\text { - Water chlorophyll data: } \\
\text { determination of primary productivity. }\end{array}$ & Szuster and Albasri (2010) \\
\hline$C 2$ & $\begin{array}{l}\text { ENVIRONMENTAL } \\
\text { FACTORS }\end{array}$ & & Zonneveld et al. (1991) \\
\hline MC3 & Location suitability & $\begin{array}{l}\text { The location chosen is the one that is } \\
\text { easiest to reach. With the cultivation } \\
\text { location, which is relatively close to } \\
\text { the household where it lives, it will be } \\
\text { easier to maintain. }\end{array}$ & Zonneveld et al. (1991) \\
\hline MC4 & $\begin{array}{l}\text { Availability of factor production } \\
\text { and support facilities }\end{array}$ & $\begin{array}{l}\text { Without factor production, such as } \\
\text { humans and supporting facilities, this } \\
\text { marine cultivation will not work. } \\
\text { The main factor besides nature is } \\
\text { humans themselves, who are engaged } \\
\text { in cultivation. }\end{array}$ & Zonneveld et al. (1991) \\
\hline MC5 & $\begin{array}{l}\text { Public perception and } \\
\text { participation of the environment }\end{array}$ & $\begin{array}{l}\text { A lively and supportive public view is } \\
\text { needed for marine cultivation } \\
\text { otherwise it will be difficult in the } \\
\text { development process without } \\
\text { residents' support. }\end{array}$ & Zonneveld et al. (1991) \\
\hline C3 & ECOLOGICAL FACTORS & & Munasinghe (2002) \\
\hline MC6 & Use of floating net cage system & $\begin{array}{l}\text { The development of this method can } \\
\text { not separate from the direction of } \\
\text { environmentally friendly cultivation } \\
\text { because the issue of fish farming, } \\
\text { which is identical to pollution, is a very } \\
\text { compassionate matter. Therefore, } \\
\text { both cultivation technology and } \\
\text { materials and equipment used must } \\
\text { have specific standards by } \\
\text { environmentally friendly criteria. }\end{array}$ & Charles (2001) \\
\hline MC7 & $\begin{array}{l}\text { Preservation of the form and } \\
\text { function of natural ecosystems }\end{array}$ & $\begin{array}{l}\text { Cultivation must be accompanied by } \\
\text { conservation to preserve and sustain } \\
\text { the cultivation ecosystem in the long } \\
\text { term. }\end{array}$ & Charles (2001) \\
\hline
\end{tabular}




\section{Research Methodology}

\subsection{Data Collection}

In this study, the primary data was collected through an online questionnaire, which was sent to several relevant respondents. The questionnaire was developed on SurveyMonkey and shared with the potential respondents. Twelve people filled the questionnaire correctly, and their data was used for analysis through three models, discussion of which is presented in the succeeding section. The copy of the questionnaire can be obtained from the author on a reasonable request.

\subsection{Data analysis techniques}

3.2.1 Grey Absolute Decision Analysis. Grey System Theory was proposed in 1982 by Professor Deng Julong and is a powerful tool for processing uncertain information (Du et al., 2021; Deng, 1982). Liu's Absolute Grey Relation Analysis (AGRA) is one of the essential parts of grey system theory (Liu, Yang \& Forrest, 2017; Javed \& Liu, 2019). The grey system here is assumed to be a system where some information is known, and some information is unknown (Fahim et al., 2021; Javed et al., 2020a). The theory is valuable when data is small, and data distribution is not a matter of concern (Javed et al., 2020b; Mahmoudi et al., 2020a). The theory allows us to view systems and data in white-grey-black spectrum, where data uncertainty is always in the middle, which refers to somewhere in the grey area (Javed et al., 2021; Mahmoudi et al., 2019). The grey analysis then forms a series of clear statements regarding the system's solution, unclear and incomplete data (Mahmoudi et al., 2020b). Therefore, this system will provide various available solutions. The grey analysis may not produce the best solutions but it offers good solutions, the right solution to real-world problems.

Multiple criteria decision making (MCDM) is an essential part of operations research and has its application in various fields (Mahmoudi et al., 2020c). Grey Absolute Decision Analysis (GADA) method is one of the new developments in MCDM, and was proposed by Javed et al. (2020a) by fusing the advantages of weighted geometric mean and Liu's absolute grey relational analysis. The GADA weights represent the relative weight of alternatives against a set of criteria. The key advantages of GADA lies in its simplicity and lower computation cost (Ikram et al., 2021). The model, in its simplest form, can be represented by the following formulas,

$$
\begin{array}{ll}
\grave{\mathrm{R}}_{j}=\frac{\grave{\mathrm{r}}_{j}}{\sum_{j=1}^{S} \grave{\mathrm{r}}_{j}} & \grave{\mathrm{R}}_{j}=\frac{\grave{\mathrm{r}}_{j}}{\sum_{j=1}^{S} \grave{\mathrm{r}}_{j}} \\
\grave{\mathrm{r}}_{j}=\left(\prod_{j=1}^{S} r_{j}^{\alpha_{i}}\right)^{1 / \sum_{i=1}^{N} \alpha_{i}} & \grave{\mathrm{r}}_{j}=\left(\prod_{j=1}^{S} \grave{\mathrm{r}}_{j}^{\delta(k)}\right)^{1 / \sum_{k=1}^{M} \delta(k)}
\end{array}
$$

where, $\alpha_{i}=\frac{1}{N}\left(\varepsilon_{i 1}+\varepsilon_{i 2} \ldots+\varepsilon_{i N}\right)$, and $\grave{\mathrm{r}}_{j}$ and $\grave{\mathrm{r}}_{j}$ represent GADA Indexes and $\grave{\mathrm{R}}_{j}$ and $\grave{\mathrm{R}}_{j}$ represent GADA weights. Meanwhile, If the zero-starting point images of criteria $Y_{i}$ and $Y_{j}$ are $Y_{i}^{0}=$ $\left(y_{i}^{0}(1), y_{i}^{0}(2), \ldots, y_{i}^{0}(\mathrm{n})\right)$ and $Y_{j}^{0}=\left(y_{\mathrm{j}}^{0}(1), y_{\mathrm{j}}^{0}(2), \ldots, y_{\mathrm{j}}^{0}(\mathrm{n})\right)$ then the absolute grey relational grade is given by

$$
\varepsilon_{i j}=\frac{1+\left|s_{i}\right|+\left|s_{j}\right|}{1+\left|s_{i}\right|+\left|s_{j}\right|+\left|s_{i}-s_{j}\right|}
$$

where,

$$
\begin{gathered}
\left|s_{i}\right|=\left|\sum_{k=2}^{n-1} y_{i}^{0}(k)+\frac{1}{2} y_{i}^{0}(n)\right|,\left|s_{j}\right|=\left|\sum_{k=2}^{n-1} y_{j}^{0}(k)+\frac{1}{2} y_{j}^{0}(n)\right| \\
\left|s_{i}-s_{j}\right|=\left|\sum_{k=2}^{n-1}\left(y_{i}^{0}(k)-y_{j}^{0}(k)\right)+\frac{1}{2}\left(y_{i}^{0}(n)-y_{j}^{0}(n)\right)\right|
\end{gathered}
$$

For further information and detailed computational steps governing the GADA model and Absolute Grey Relational Analysis, Javed et al. (2020a) and Liu et al. (2017) can be consulted, respectively. 
Table 4. The Response Sheet and Aggregation

\begin{tabular}{|c|c|c|c|c|c|c|c|}
\hline & MC1 & MC2 & MC3 & MC4 & MC5 & MC6 & MC7 \\
\hline R1 & 5 & 5 & 4 & 4 & 3 & 4 & 5 \\
\hline R2 & 5 & 5 & 4 & 4 & 4 & 4 & 4 \\
\hline R3 & 5 & 4 & 4 & 3 & 4 & 4 & 5 \\
\hline R4 & 4 & 4 & 4 & 4 & 4 & 4 & 5 \\
\hline R5 & 3 & 3 & 4 & 2 & 3 & 5 & 3 \\
\hline R6 & 5 & 5 & 4 & 4 & 4 & 4 & 4 \\
\hline R7 & 5 & 4 & 4 & 4 & 4 & 5 & 5 \\
\hline R8 & 4 & 4 & 4 & 5 & 5 & 4 & 4 \\
\hline R9 & 5 & 5 & 4 & 4 & 4 & 5 & 5 \\
\hline R10 & 5 & 5 & 5 & 5 & 5 & 5 & 5 \\
\hline R11 & 5 & 4 & 5 & 4 & 4 & 4 & 3 \\
\hline R12 & 4 & 3 & 2 & 3 & 3 & 2 & 2 \\
\hline GM & 4.53 & 4.18 & 3.92 & 3.74 & 3.86 & 4.07 & 4.02 \\
\hline
\end{tabular}

Table 5. Estimating $\alpha_{i}$ and $\sqrt{\alpha_{i}(\mathrm{k})}$

\begin{tabular}{|c|l|l|l|l|l|l|l|l|l|l|l|l|l|c|}
\hline $\boldsymbol{\varepsilon}$ & $\mathrm{R} 1$ & $\mathrm{R} 2$ & $\mathrm{R} 3$ & $\mathrm{R} 4$ & $\mathrm{R} 5$ & $\mathrm{R} 6$ & $\mathrm{R} 7$ & $\mathrm{R} 8$ & $\mathrm{R} 9$ & $\mathrm{R} 10$ & $\mathrm{R} 11$ & $\mathrm{R} 12$ & $\boldsymbol{\alpha}_{\boldsymbol{i}}$ & $\sqrt{\boldsymbol{\alpha}_{\boldsymbol{i}}(\mathbf{k})}$ \\
\hline R1 & 1.000 & 1.000 & 0.923 & 0.636 & 0.727 & 1.000 & 0.909 & 0.727 & 0.818 & 0.546 & 0.923 & 0.790 & 0.833 & 0.913 \\
\hline R2 & 1.000 & 1.000 & 0.923 & 0.636 & 0.727 & 1.000 & 0.909 & 0.727 & 0.818 & 0.546 & 0.923 & 0.790 & 0.833 & 0.913 \\
\hline R3 & 0.923 & 0.923 & 1.000 & 0.615 & 0.692 & 0.923 & 0.846 & 0.692 & 0.769 & 0.539 & 1.000 & 0.842 & 0.814 & 0.902 \\
\hline R4 & 0.636 & 0.636 & 0.615 & 1.000 & 0.800 & 0.636 & 0.667 & 0.800 & 0.714 & 0.667 & 0.615 & 0.579 & 0.697 & 0.835 \\
\hline R5 & 0.727 & 0.727 & 0.692 & 0.800 & 1.000 & 0.727 & 0.778 & 1.000 & 0.857 & 0.600 & 0.692 & 0.632 & 0.769 & 0.877 \\
\hline R6 & 1.000 & 1.000 & 0.923 & 0.636 & 0.727 & 1.000 & 0.909 & 0.727 & 0.818 & 0.546 & 0.923 & 0.790 & 0.833 & 0.913 \\
\hline R7 & 0.909 & 0.909 & 0.846 & 0.667 & 0.778 & 0.909 & 1.000 & 0.778 & 0.889 & 0.556 & 0.846 & 0.737 & 0.819 & 0.905 \\
\hline R8 & 0.727 & 0.727 & 0.692 & 0.800 & 1.000 & 0.727 & 0.778 & 1.000 & 0.857 & 0.600 & 0.692 & 0.632 & 0.769 & 0.877 \\
\hline R9 & 0.818 & 0.818 & 0.769 & 0.714 & 0.857 & 0.818 & 0.889 & 0.857 & 1.000 & 0.571 & 0.769 & 0.684 & 0.797 & 0.893 \\
\hline R10 & 0.546 & 0.546 & 0.539 & 0.667 & 0.600 & 0.546 & 0.556 & 0.600 & 0.571 & 1.000 & 0.539 & 0.526 & 0.603 & 0.776 \\
\hline R11 & 0.923 & 0.923 & 1.000 & 0.615 & 0.692 & 0.923 & 0.846 & 0.692 & 0.769 & 0.539 & 1.000 & 0.842 & 0.814 & 0.902 \\
\hline R12 & 0.790 & 0.790 & 0.842 & 0.579 & 0.632 & 0.790 & 0.737 & 0.632 & 0.684 & 0.526 & 0.842 & 1.000 & 0.737 & 0.858 \\
\hline
\end{tabular}

Table 6. Rankings of the site selection criteria

\begin{tabular}{|c|c|c|c|c|c|c|c|}
\hline & MC1 & MC2 & MC3 & MC4 & MC5 & MC6 & MC7 \\
\hline$\ddot{\mathrm{r}}$ & 4.5471 & 4.1920 & 3.9173 & 3.7212 & 3.8456 & 4.0675 & 4.0224 \\
\hline$\ddot{\mathrm{R}}$ & 0.2776 & 0.2560 & 0.2392 & 0.2272 & 0.2348 & 0.2484 & 0.2456 \\
\hline Ranking & 1 & 2 & 5 & 7 & 6 & 3 & 4 \\
\hline
\end{tabular}

Table 7. Comparative Analysis of GADA with SAW and TOPSIS

\begin{tabular}{|l|c|c|c|c|c|c|}
\hline \multirow{2}{*}{ Site Selection Criteria } & \multicolumn{2}{|c|}{ GADA } & \multicolumn{2}{c|}{ SAW } & \multicolumn{3}{c|}{ TOPSIS } \\
\cline { 2 - 8 } & Weight & Rank & Weight & Rank & Weight & Rank \\
\hline MC1: Oceanographic conditions & 0.2776 & 1 & 0.2246 & 1 & N/A & 1 \\
\hline MC2: Water quality & 0.2560 & 2 & 0.2082 & 2 & N/A & 3 \\
\hline MC3: Location suitability & 0.2392 & 5 & 0.1960 & 5 & $N / A$ & 5 \\
\hline $\begin{array}{l}\text { MC4: Availability of factor production and } \\
\text { support facilities }\end{array}$ & 0.2272 & 7 & 0.1878 & 7 & N/A & 7 \\
\hline $\begin{array}{l}\text { MC5: Public perception and participation of the } \\
\text { cultivation }\end{array}$ & 0.2348 & 6 & 0.1919 & 6 & N/A & 6 \\
\hline MC6: Use of floating net cage system & 0.2484 & 3 & 0.2041 & 4 & $N / A$ & 2 \\
\hline $\begin{array}{l}\text { MC7: Preservation of the form and function of } \\
\text { natural ecosystems }\end{array}$ & 0.2456 & 4 & 0.2041 & 3 & $N / A$ & 4 \\
\hline$* N / A:$ Not Applicable as TOPSIS cannot estimate weights & & & & & \\
\hline
\end{tabular}


3.2.2 Simple Additive Weighting. Simple Additive Weighting (SAW) is also known as the weighted addition method. The SAW method's basic concept is to discover the weighted sum of each alternative's performance ratings on all attributes (Simanaviciene \& Ustinovichius, 2010; Fishburn, 1967). The SAW method requires a decision matrix normalization process to a scale comparable to all existing alternative ratings. This method is the most well-known and most widely used method of dealing with MCDM problems. This method requires helps determine the weight of each alternative based on the weights. The other options' total score obtains by adding up all multiplication results among scale and weight for each feature. The computational steps of SAW as reported in Afshari et al. (2010) were used in the current study.

3.2.3 TOPSIS. Technique for Order Preference by Similarity to Ideal Solution (TOPSIS) was proposed in the 1980s by K. Yoon in his PhD dissertation (Yoon, 1980; Hwang \& Yoon, 1981). It is one of the most influential MCDM methods. TOPSIS ranks the alternatives based on their distance from positive (best) and negative (worst) ideal alternatives (Zare et al., 2018). TOPSIS has several benefits e.g., simplicity, rational, comprehensibility, reasonable computational cost and capability to produce relative performance of alternatives using simple mathematics (Ikram et al., 2020). Also it has an appropriate performance when a decision matrix instead of a pairwise comparison matrix is available to data analyst (Mahmoudi et al., 2020c). The computational steps of TOPSIS as reported in Hwang and Yoon (1981) were used in the current study.

\section{Data and results}

\subsection{Site Selection through $G A D A$}

This study is group decision-making to determine the site selection of marine cultivation, which is proven and analyzed using the GADA method. We have seven alternatives / possible criteria in determining the site selection of marine cultivation (MC: seven criteria in determining the location of cultivation) and 12 independent decision-makers (R: expert). Since the study's objective is to rank the criteria therefore the experts' opinions about their importance was sought using 5-point Likert scale, as shown in Table 4, where " 1 " deputizes the lowest score, " 5 " deputizes the highest score. All have higher the better characteristic. Thus, concerning MC, score " 1 " is the worst, and score " 5 " is the best one. The execution of the GADA method is shown in Tables 5 and 6.

\subsection{Comparative Analysis with SAW and TOPSIS}

The comparative analysis of the results obtained through GADA method are compared with those of SAW and TOPSIS methods in Table 7. Figure 2 illustrates the comparison of the rankings of the three methods. The comparative analysis reveals that their results are comparable though not entirely. However, according to all methods the oceanographic conditions (MC1) is the top scorer, the most important criteria for site selection for marine cultivation.

MC 7: Preservation of the form and function of...

MC 6: Use of floating net cage system

MC 5: Public perception and participation of...

MC 4: Availability of factor production and...

MC 3: Location suitability

MC 2: Water quality

MC 1: Oceanographic conditions
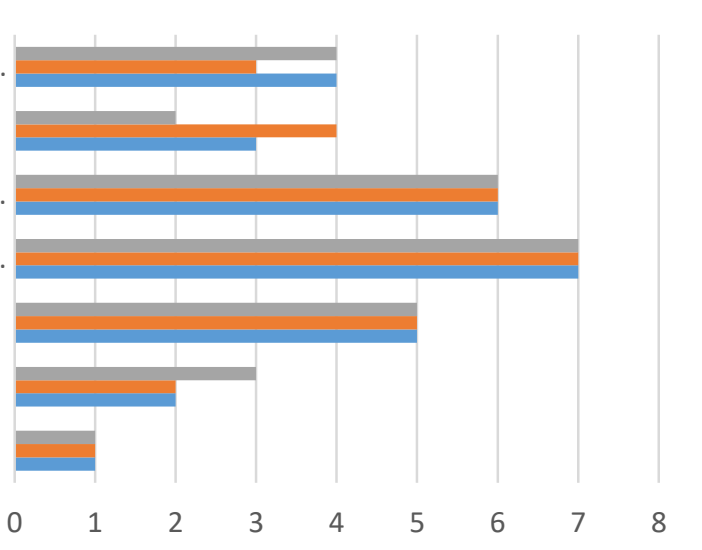

-TOPSIS $\square$ SAW $\square$ GADA

Figure 2. Rankings obtained through GADA, SAW, and TOPSIS 
According to the GADA method, Oceanographic conditions (MC1) gets the highest order relative weight means selected to be the most critical criterion. It followed by Water quality (MC2), Use of floating net cage system (MC6), Preservation of the form and function of natural ecosystems (MC7), Location suitability (MC3), Public perception and participation of the cultivation (MC5), Availability of factor production and support facilities (MC4). The results from GADA were mostly comparable with those of SAW and TOPSIS except for the second, sixth and seventh criteria, as can be seen from Table 7. For the Water quality (MC2), GADA and SAW ranked it second while TOPSIS ranked it third most important criteria for site selection, while for Preservation of the form and function of natural ecosystems (MC7), GADA and TOPSIS categorized it as fourth while SAW ranked it as third. For Use of floating net cage system (MC6), the methods failed to achieve consensus and ensemble ranking (Mohammadi \& Rezaei, 2020) may be needed. Overall, the results are realistic and convincing.

\section{Conclusion and recommendations}

Cultivation activities are one of the popular activities in Indonesia. It is undeniable that Indonesia's natural wealth makes it one of the main factors in implementing a cultivation system to optimize natural resources and improve human resources. It provides a positive boost to Indonesia's economic development. Marine cultivation often in all countries with extensive water areas, one of which is Indonesia, an archipelago country. This activity certainly positively impacts the land itself; high productivity can cultivate an export commodity to countries in need and meet domestic market demand. However, in determining any cultivation, determining or supporting factors are needed in the activity. Here, the author focuses on marine cultivation applied in North Lombok, which is already known for its marine wealth and extraordinary ecosystems and opportunities.

Cultivation activities as one of Indonesia's facilities and infrastructure in developing and optimizing natural products, of course, require a thorough review before being carried out so that the sustainability of cultivation is sustainable. With the multi-criteria decision-making model applied to 12 related people and analysed using the GADA, SAW and TOPSIS systems, the author has researched and is responsible for the resulting data that is not engineered and original. The results obtained are likely to benefit decision-makers and parties involved in determining marine culture's location. The determination of marine culture location based on the results and discussion shows that oceanographic conditions are the most critical factor in determining cultivation location. The criteria for each alternative decision cannot compare with one another; all have the same importance. The evaluation results expect to provide convenience for people who need a determinant analysis of marine cultivation locations before making decisions, such as business companies related to aquatic cultivation or domestic or foreign investors who wish to invest in marine cultivation in Indonesia in the future.

The limitation of the study lies in the limited number of respondents (experts) so that in the future, it is necessary to increase the number of decision-makers to improve the quality and validity of the data- the results obtained from the analysis of three different methods resulted in significant data similarities. Therefore, the author recommends the GADA method as a convenient and straightforward method for researchers based on Multi-Criteria Decision Making. The study confirms that the GADA method's advantage in analysing complex problems through simple steps, and ability to handle small samples, make it a promising approach to handle MCDM problems. In future, the GADA method can be extended to make its results more optimum, especially in linguistic environment.

\section{References}

Affan, J. M. (2011). Selection of location for cultivation development in floating net cages based on environmental factors and water quality in the eastern coastal waters of Central Bangka Regency. Jurnal Sains MIPA Universitas Lampung, 17 (3), 99-106. https://jurnal.fmipa.unila.ac.id/sains/article/view/351

Afshari, A., Mojahed, M., Yusuff, R. M. (2010). Simple Additive Weighting approach to Personnel Selection problem. International Journal of Innovation, Management, and Technology, 1(5). http://ijimt.org/papers/89M474.pdf

Charles, A. T. (2001). Sustainable Fishery System. Blackwell Science Ltd. Oxford.

Deng, J. (1982). Control problems of grey systems. Systems \& Control Letters, 1(5), 288-294. https://doi.org/10.1016/S0167-6911(82)80025-X

Du, J., Liu, S., \& Liu, Y. (2021). A novel grey multi-criteria three-way decisions model and its application. Computers \& Industrial Engineering, 158, 107405. https://doi.org/10.1016/j.cie.2021.107405 
Fahim, A., Addae, B.A., Ofosu-Adarkwa, J., Qingmei, T., \& Bhatti, U.A. (2021). Industry 4.0 and Higher Education: An Evaluation of Barriers Affecting Master's in Business Administration Enrolments Using a Grey Incidence Analysis. IEEE Access, 9, 76991 - 77008. https://doi.org/10.1109/ACCESS.2021.3082144

FAO. (1989). Site selection criteria for marine finfish net cage culture in Asia. Rome: Food and Agricultural Organization.

FAO. (2020). The State of World Fisheries and Aquaculture 2020. Sustainability in action. Rome: Food and Agricultural Organization. https://doi.org/10.4060/ca9229en

Fishburn, P. C. (1967). A Problem-based Selection of Multi-Attribute Decision Making Methods. New Jersey: Blackwell Publishing

Gimin, R. (2001). Opportunities and Barriers to Aquaculture Development in NTT Province. Proceedings of the Seminar on Research Results and Studies by UPT Fisheries and Marine Sciences UNDANA, Kupang. https://seminarfkp.undana.ac.id/Uploads/FileProsiding/Prosiding_FKP_Undana_1.pdf

Hartoko, A., \& Helmi, M. (2004). Development of Digital Multilayer Ecological Model for Padang Coastal Water (West Sumatera). Journal of Coastal Development, 7(3), 129-136. https://ejournal.undip.ac.id/index.php/coastdev/article/view/5250

Hwang, C. L. and Yoon, K. (1981). Multiple Attribute Decision Making: Methods and Applications. Springer-Verlag, New York. http://dx.doi.org/10.1007/978-3-642-48318-9

Ikram, M., Sroufe, R., \& Zhang, Q. (2020). Prioritizing and overcoming barriers to integrated management system (IMS) implementation using AHP and G-TOPSIS. Journal of Cleaner Production, 254, 120121. https://doi.org/10.1016/j.jclepro.2020.120121

Ikram, M., Zhang, Q., Sroufe, R., \& Ferraso, M. (2021). Contribution of Certification Bodies and Sustainability Standards to Sustainable Development Goals: An Integrated Grey Systems Approach. Sustainable Production and Consumption, 28, 326-345. https://doi.org/10.1016/j.spc.2021.05.019

Javed S. A, Zhu, B., \& Liu S. (2020b). Forecast of Biofuel Production and Consumption in Top CO2 Emitting Countries using a novel grey model. Journal of Cleaner Production, 276, 123977. https://doi.org/10.1016/j.jclepro.2020.123997

Javed, S. A., \& Liu, S. (2019). Bidirectional Absolute GRA/GIA model for Uncertain Systems: Application in Project Management. IEEE Access, 7(1), 60885-60896. https://doi.org/10.1109/ACCESS.2019.2904632

Javed, S. A., Ikram, M., Tao, L., \& Liu, S. (2021). Forecasting Key Indicators of China's Inbound and Outbound Tourism: Optimistic-Pessimistic Method. Grey Systems: Theory and Application, 11(2). 265-287. https://doi.org/10.1108/GS-12-2019-0064

Javed, S. A., Mahmoudi, A., \& Liu, S. (2020a). Grey Absolute Decision Analysis (GADA) method for Multiple Criteria Group Decision Making under Uncertainty. International Journal of Fuzzy Systems, 22(4), 1073-1090. https://doi.org/10.1007/s40815-020-00827-8

Junaidi, M., Nurliah, Marzuki, M., Cokrowati, N., \& Rahman, I. (2018). Identification of Water Locations for Marine Aquaculture Development in North Lombok Regency. Jurnal Biologi Tropis, 18(1). 57-69. http://dx.doi.org/10.29303/jbt.v18i1.730

Liu, S., Yang, Y., \& Forrest, J. (2017). Grey data analysis: Methods, models and applications. Singapore: Springer Singapore. ISBN 978-981-10-1841-1.

Mahmoudi, A., Bagherpour, M., \& Javed, S.A. (2019). Grey Earned Value Management: Theory and Applications. IEEE Transactions on Engineering Management. https://doi.org/10.1109/TEM.2019.2920904

Mahmoudi, A., Deng, X., Javed, S. A., \& Yuan, J. (2020c). Large-Scale Multiple Criteria Decision-Making with Missing Values: Project Selection through TOPSIS-OPA. Journal of Ambient Intelligence and Humanized Computing. https://doi.org/10.1007/s12652-020-02649-w

Mahmoudi, A., Deng, X., Javed, S. A., \& Zhang, N. (2020a). Sustainable Supplier Selection in Megaprojects through Grey Ordinal Priority Approach. Business Strategy and The Environment, 30, 318-339. https://doi.org/10.1002/bse.2623

Mahmoudi, A., Javed, S. A., Liu, S.F., \& Deng, X. (2020b). Distinguishing Coefficient driven Sensitivity Analysis of GRA Model for Intelligent Decisions: Application in Project Management. Technological and Economic Development of Economy, 26(3), 621-641. https://doi.org/10.3846/tede.2020.11890

Meske, C, \& Vogt, F. (1985). Fish Aquaculture Technology and Experiments (1 ${ }^{\text {st }}$ ed.). F. Vogt (ed). London: Pengamon Press.

Milne, P. H. (1979). Fish and Shellfish Farming in Coastal Waters. Fishing News Book Ltd, Farnham Surrey.

Mohammadi, M., \& Rezaei, J. (2020). Ensemble ranking: Aggregation of rankings produced by different multicriteria decision-making methods. Omega, 96, 102254. https://doi.org/10.1016/j.omega.2020.102254

Muir, J. F., Kapetsky, J. M. (1988). Site Selection Decisions and Project Cost. The Case of Brackish Water Pond System. Aquaculture Engineering Technologies for The Future. IChemE Symposium Series 111, EFCE Publication Series 66. Scotland. https://doi.org/10.15578/jppi.11.5.2005.31-41

Munasinghe, M. (2002). Analyzing the nexus of sustainable and climate change: An overview. France: OECD.

Pillay, T. V. R. (1990). Quality Criteria for Water. Washington, DC: US Environmental Protection Agency. JakartaBandung: Agency for Agriculture and Development Ministry of Agriculture. 
Radiarta, I.N., Saputra, A., Priono, B. (2005). Identification of the feasibility of fish farming land in floating net cages with the application of geographic information systems in Pangpang Bay, East Java. Indonesian Fisheries Research Journal, 11(5), 1-13. http://dx.doi.org/10.15578/jppi.11.5.2005.31-41

Simanaviciene, R., \& Ustinovichius, L. (2010). Sensitivity Analysis for Multiple Criteria Decision Making Methods: TOPSIS and SAW. Procedia - Social and Behavioral Science, 2, 7743-7744. https://doi.org/10.1016/j.sbspro.2010.05.207

Statista. (2020). Contribution of fisheries to the gross domestic product (GDP) in Indonesia from 2014 to 2019. Statista. https://www.statista.com/statistics/1083946/indonesia-fisheries-contribution-to-gdp

Sukandi, M.F. (2002). The Improvement of Fish Culture Technology. Journal Icthyoligi Indonesia, 2(2), 61-66. https://doi.org/10.32491/jii.v2i2.279

Szuster, W.B., \& Albasri, H. (2010). Site selection for grouper mariculture in Indonesia. International Journal of $\begin{array}{llll}\text { Fisheries } \quad \text { and } & \text { Aquaculture, }\end{array}$ https://academicjournals.org/article/article1379436090_Szuster\%20and\%20Albasri.pdf

TMAF. (2021). Perikanan. Department of Transportation, Maritime Affairs and Fisheries. http://www.lombokutarakab.go.id/v1/images/katalog_potensi_daerah/perikanan/perikanan.pdf

Torres, A. C., Ross, L.G., Beveridge, M.C.M. (1998). The Use Remote Sensing in Water Quality Investigations for Aquaculture and Fisheries. Aquaculture Engineering Technologies for The Future. IChemE Symposium Series 111, EFCE Publication Series 66. Scotland.

Utojo, U., \& Mansyur, A. (2007). Feasibility Study of Grouper (Epinephelus sp.) Cultivation Locations in the Waters of Nine Islands, Sinjai Regency, South Sulawesi. Jurnal Perikanan Universitas Gadjah Mada, 9(1), 6981. https://doi.org/10.22146/jfs.66

Widodo, J. (2001). Basic Principles of Aquaculture Development with Examples of Grouper and Milkfish Cultivation in Indonesia. Marine Cultivation Technology and Development of Sea Farming Indonesia. Ministry of Marine Affairs and Fisheries and JICA, 1, $17-26$.

Yoon, K. (1980). Systems Selection by Multiple Attribute Decision Making (Ph.D. Dissertation), Kansas State University, Manhattan, Kansas.

Zare, A., Feylizadeh, M., Mahmoudi, A., \& Liu, S. (2018). Suitable computerized maintenance management system selection using grey group TOPSIS and fuzzy group VIKOR: a case study. Decision Science Letters, 7(4), 341358. https://doi.org/10.5267/J.DSL.2018.3.002

Zonneveld, N., Huisman, E. A., \& Boon, J. H. (1991). Fish farming principles. Jakarta: PT Gramedia Pustaka Utama. ISBN 979403911X 